\title{
The potential of intermodal transport projects in Romania
}

\author{
Alexandra TUDORICA \\ The Bucharest University of Economic Studies, Bucharest, Romania \\ alexandratudorica@yahoo.com \\ Cristian Silviu BANACU \\ The Bucharest University of Economic Studies, Bucharest, Romania
}

\begin{abstract}
The transport infrastructure sector is facing challenges related to the decarbonisation, financing and integrated developments, which need to be overcome so it can gain a competitive advantage among the strategic economic sectors. Known as a major pollutant, with $23.3 \%$ of the total EU-28 GHG emissions in 2014, one of the transport policy objectives is to lower this percentage, by focusing on innovative solutions and modal shift (Eurostat, 2016). The White Paper (2011) promotes a sustainable development, aiming at a reduction by $60 \%$ by 2050 of the carbon emissions generated by the transport sector and at a modal shift from road to rail or waterborne transport for freight transport over $300 \mathrm{~km}$ with 30\% by 2030, and more than $50 \%$ by 2050. The focus on an integrated development of the transport sector at the European level was reinforced with the adoption of the EU Regulation no. 1315/2013, marking the transition from a patchwork of different projects towards a vision for the achievement of an EU transport network. Moreover, another challenge is related to the scarce availability of the public money, making it necessary to attract private parties in the development of the transport infrastructure projects (The Investment Plan for Europe, 2014). Supporting the development of the intermodal transport is a way of surmounting the obstacles that this sector is confronting with, which is being implemented in Europe. The intermodal transport is introducing a paradigm shift, allowing the integration of the different transport modes together with their own advantages, as opposed to competing stand-alone modes and it can aid in the fight against climate change, scarce financial resources and congestion This article aims at determining the potential of Romania, as a member of European Union, to develop intermodal transport projects, to identify the funding sources, the obstacles and the solutions to promote the successful implementation of such projects.
\end{abstract}

Keywords: intermodal transport, project management, Romania.

\section{Introduction}

The intermodal transport is defined as "the combination of at least two modes of transport in a single transport chain, without a change of container for goods, with most of the route travelled by rail, inland waterway and ocean-going vessel and with the shortest possible initial and final journeys by road" (Macharis and Bontekoning, 2004).

Although the term "intermodal transport" is used since 1960s, it gained momentum only in the past years (Donovan, 2000). Making a literature review, Mathisen and Hanssen (2014) noted that 33\% out of 239 articles (released between the years 1985-2013) were published in 2011 to 2013. In addition, the management of such projects was not sufficiently addressed in the literature. The increased attention during the last years is in connection with the issues that the transport sector is facing, namely the road congestion, globalization, traffic safety, environmental problems, pollution. In this respect, the European Union tried to solve these stringent obstacles via its policies, integrated approach of the transport projects and financing/funding initiatives, be it public only or PPP 
(Pedersen, et al., 2005; Macharis, et. al., 2011). The challenges that this sector is confronting with were addressed in the EU Regulation no. 1315/2013, the focus on the development of the TEN-T network being made at the EU level rather than only national level, by promoting the infrastructure projects to solve the capacity issues, missing links, (cross-border) bottlenecks, development of rail/road terminals and accessibility improvement. Moreover, the Connecting Europe Facility competitive calls from 2014, ruled by the EU Regulation no. $1316 / 2013$, revealed the fact that the projects were oversubscribed: the available budget was $€ 11.93$ billion euros (out of €22.4 billion euros) and the total amount of money requested for the projects was surpassing it with more than 1 billion euros (European Parliament, 2015). The need for private money could be justified so as to manage to complete the TEN-T Transport Network, idea which is supported by the Juncker Plan as well. Nonetheless, the environmental challenges are reinforced not only by the White Paper (2011), but by the other transport policies as well, focusing on the promotion of sustainable transport solutions and, among others, the intermodal terminals/ multimodal transport chains (Art. 50 from EU Regulation no. 1315/2013).

Even though the development of intermodal transport was listed as "the most critical action to achieve a sustainable transport sector", the promotion of such transport projects did not progress with the expected pace (Mathisen and Hanssen, 2014; Janic, 2007 in Mathisen and Hanssen, 2014).

Following the EU trends, in Romania there were some dedicated actions (including a related strategy), but the field was not sufficiently developed. The scope of this article aims at determining the potential of Romania to develop/implement intermodal transport projects, assuming as an initial hypothesis that Romania's potential to develop intermodal transport projects is very high. Before moving to the next section, a distinction has to be made. The intermodal transport can be either for passengers or freight and it can be differentiated according to the transport mode as: aerial, road, rail, maritime and inland waterway (Nistor, 2013). For the purpose of this article, the focus is on freight and rail/road intermodal transport. The reminder of the article is as follows: the literature (and sector) review regarding the intermodal transport in general and in particular for Romania, the research methodology and the conclusions.

\section{Research methodology}

In order to determine the potential of Romania to develop/implement intermodal infrastructure projects a desk research was conducted aiming at making an inventory of the available literature, the policies related to the field of study, the studies/analyses/projects which were carried out and some discussions with professionals involved in the transport field. The literature review is summarized below. The identified trends and characteristics of the intermodal transport field were confirmed during the discussions.

\section{Literature review}

As mentioned earlier, the management of intermodal transport project was not widely addressed in the literature. For example, a search by the keywords "intermodal" and "project management" present in the keywords, title or abstract of the articles and published after 2007 in the Science Direct database lead to 5 results, the search for "intermodal" and "management" lead to 36 and to 1 result for "inter-modal" and "Romania". 


\section{The characteristics of intermodal transport}

The intermodal freight transport system has to face many challenges due to the integration of various transport modes which need to be coordinated, but it presents multiple advantages as well and it can be seen as a new transport mode (Caris, et al., 2013). It can be considered as a new transport mode consisting in an integrated system which presents the advantage of each mode involved in the chain (Floden, 2007 in Mathisen and Hanssen, 2014). These advantages can be translated into economic terms, by lowering the variable costs via the economy of scale obtained through moving the consolidated freight in the same transport and in large quantities during the main haulage (Pedersen, et al., 2005; Macharis, et al., 2011; Dragu, 2009). From the environmental point of view, the intermodal transport is considered as a priority to achieve a sustainable transport sector due to its low external costs (e.g. accidents, noise, air pollution, congestion) and less energy-intensive characteristics (Woodburn et al., 2007 in Mathisen and Hanssen, 2014; Dragu, 2009; Macharis, et al., 2011).

The complexity of the intermodal transport arises from the involvement of multiple stakeholders/decision-makers (policy-makers, governmental bodies, infrastructure managers, operators, shippers, etc.) which need to be coordinated in an efficient manner to ensure a smooth functioning of the system (Caris, et al., 2013; Macharis, et al., 2011).

The intermodal transport is feasible from the financial perspective for long distances transport (Dragu, 2009). In his article, professor Dragu (2009) noted that the main difficulties in promoting the intermodal transport are its incapacity to respond to a modern logistic demand, organizational, technical (lack of the standardization, of door-to-door tracking systems), infrastructure, operational, economic and financial, as well as political obstacles. In Europe, the intermodal transport system is not very well developed, exception being made for The Netherlands and Belgium (Mathisen and Hanssen, 2014; Macharis, et al., 2011).

The intermodal rail freight transport system is of strategic importance at EU level, given the fact that the railway network exists and it can be fully extended/upgraded to a general standard (as promoted in EU Regulation 1315/2013) and EU-wide (Pedersen, et al., 2005). Nevertheless, the railway system is a homogenous one at EU level, having some interoperability issues (different speeds, different electrical systems, gauges etc.).

\section{Policies}

Having as priority the modal shift to rail, or other more environmental friendly transport modes, the economic efficiency, the policy makers have a strong interest in promoting the intermodal transport, at all political levels (Caris, et al., 2013; Mathisen and Hanssen, 2014; Macharis, et al., 2011). In their article Macharis et al. (2011, p.169) noted: "The policymaker's role is to assure an environment for a smooth functioning market, maintain a complete and interoperable multimodal transport network and promote its optimised use to minimise environmental externalities."

Based on a co-modal approach, the policy papers released at all levels - from European Commission to national, regional or local levels- promotes and aims at increasing the awareness of the advantages of the single transport system and of the integrated ones, as discussed as well in the context of this paper (Macharis, et al., 2011; Caris, et al., 2013). 


\section{The intermodal transport in Romania}

The potential of Romania to develop the intermodal transport system is increased by the presence of Constanta Port, being the largest port at the Black Sea and accommodating the largest container terminal, and by the fact that the Romanian territory underlines the two axes of Rail Freight Corridor 7 (nowadays the Orient/East-Med Rail Freight Corridor, underlying the TEN-T Orient/East-Med and Rhine-Danube Corridors and former PanEuropean IV and IX Corridors), making Romania an important transit country for goods from/to Western Europe (approximately $40 \%$ of the total intermodal transport volume in 2013, the rest of $60 \%$ being covered by national services, as shown in Figure 1) (COSMOS, 2013) . Moreover, the presence of the Danube River gives to Romania a strategic advantage.

Intermodal Services offered, 2013

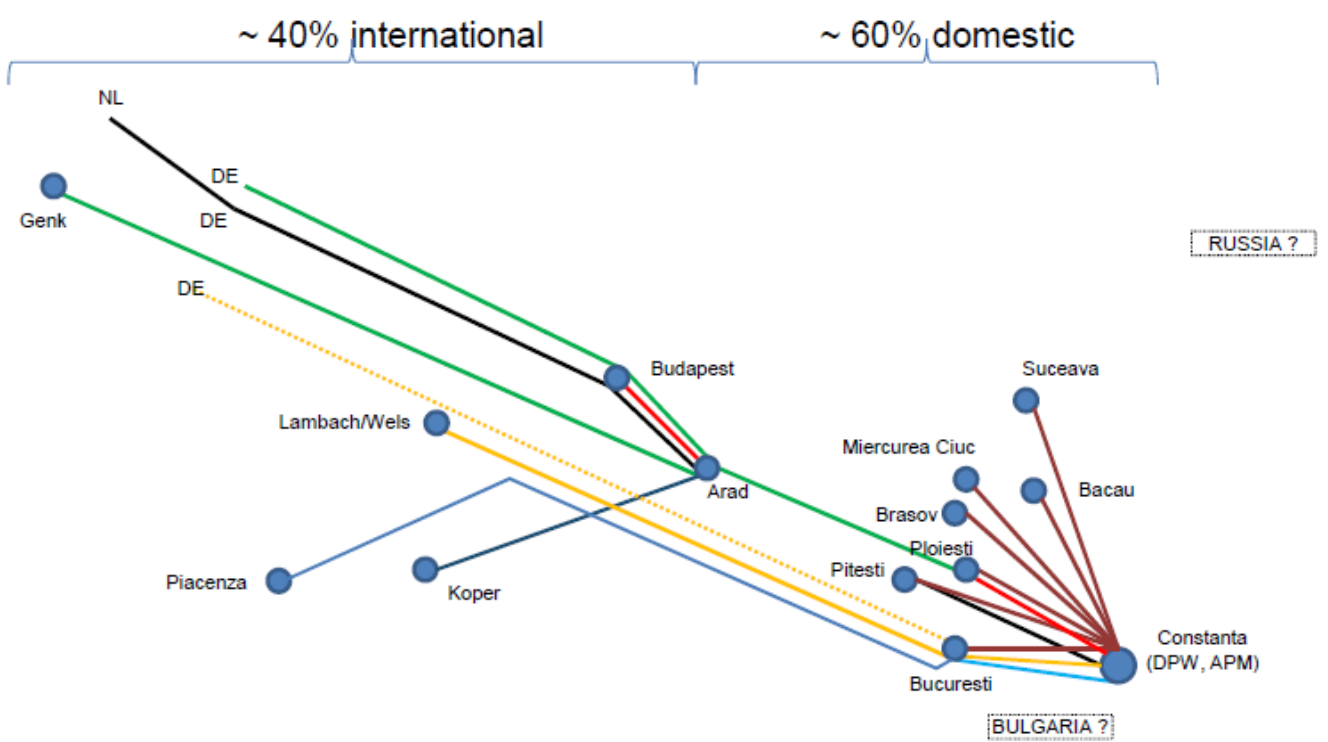

Figure 1. Intermodal services offered

Source: COSMOS, 2013.

In the International Union of Railways (UIC)'s DIOMIS study (2010), it is indicated that the backbone of the intermodal transport network in Romania should be the hinterland of Constanta Port and two terminals in Bucharest and Arad. During the years, the intermodal transport system was a permanent preoccupation of the Romanian authorities (as it can be exemplified in the text of the Law no. 203/2003), but it did not come as a priority until 2011 when the Intermodal Transport Strategy in Romania 2020 emerged. The general objective was to develop the national intermodal freight transport system to improve the efficiency of freight transport and the environmental and safety impact of the transport. Among the specific objectives defined in the Strategy were the construction/building the intermodal terminals and the adjacent infrastructure, the development of qualitative intermodal services, the promotion of the national intermodal transport system. The planned budgets were: 61 million Euros for the period 2011-2013 and 114 million Euros for 2014-2020. In 2011, a dedicated financing priority axis -3. Modernization of the transport sector aiming at higher degree of environmental protection, human health and passenger safety- Major Domain of intervention 3.1. - The promotion of intermodal transport, under the Sectoral Operational Programme "Transport" 2007-2013 was in place. According to the Guide of Applicants, the beneficiaries eligible for the call 
(making available 18.019.383 Euro) was the National Railway Intermodal Infrastructure Manager "CFR"- S.A. having a participation/venture contract signed with the local government authorities and the key locations mentioned in the guide coincided with the ones proposed in the Strategy (agreed based on the national development strategy): Timisoara, Bucuresti, Constanta, Giurgiu/Calarasi (Oltenita), Brasov and Suceava. However, the national legislation was one of the main obstacles in the realisation of such projects. In 2014, another Guide for Applicants was released, making available 2.941.176 Euro, but this time the eligible beneficiaries were the local government authorities from Bucuresti, Timisoara, Oradea, Turda, Iasi, Cluj-Napoca, Craiova, Bacau, Suceava, according to the key priority locations identified in the General Master Plan for Transport (version 2014). Based on the information available in the media, only Oradea received the funds, but the officials from the Ministry of Transport clarified that the money were not actually allocated (Ministry of Transport, 2011; SOP-T Guide for Applicants, 2011; SOP-T Guide for Applicants, 2014; www.ampost.ro, General Master Plan for Transport, 2016; Adevarul, 2015). Regarding the key locations, in the final version of the General Master Plan of Romania, 11 multimodal projects were identified: Bucuresti, Timisoara, Cluj-Napoca, Bacau, Oradea, Suceava, Iasi, Craiova, Turda, Giurgiu, Brasov (General Master Plan for Transport, 2016).

In 2013, under the COSMOS (Cooperative Solutions for Managing Optimized Services) project, round table sessions were organized in Slovenia, Czech Republic, Hungary, Romania, Bulgaria and Croatia, the outcome of discussions being implemented in a Road Map for the country involved. At the round table sessions stakeholders involved in the intermodal transport sector were invited to analyse/discuss the status-quo of the sector, the potential and the obstacles hindering the development of intermodal transport. In addition, some recommendations and a review of the incentives usually applied to stimulate the intermodal transport (which were actually not applied in Romania, at least at the level of 2013 when the study was conducted) were made. Among the recommendations, the revision of the Intermodal Strategy was the most notable one due to the market evolvement, the current conditions/improvements of the infrastructure. Moreover, the mapping of the terminals, as some private ones appeared, is needed. Last, but not least, another important recommendation is that "terminal investments should be accompanied by a thorough market analysis and take into account efficient train productions systems to link with other terminals" (COSMOS, 2013).

In the same road map, it is underlined that in 2012, the private sector railway market share was 53\%, one of the highest from Europe. It is expected that this share will increase as the liberalization of the railway market was regulated in the Fourth Railway Package (2016). However, if the National Railway Company "CFR"-S.A. is to be the project promoter of such projects, it has to give access to all operators to use the intermodal terminal in a non-discriminatory way.

An overview of the existing terminals in Romania (most of them state-owned by CFR Marfa and mainly out-of-service or private-owned) can be seen in Figure 2. Intermodal Terminals in Romania and the most active ones in the Figure 3 (COSMOS, 2013; Club Feroviar, 2013). 


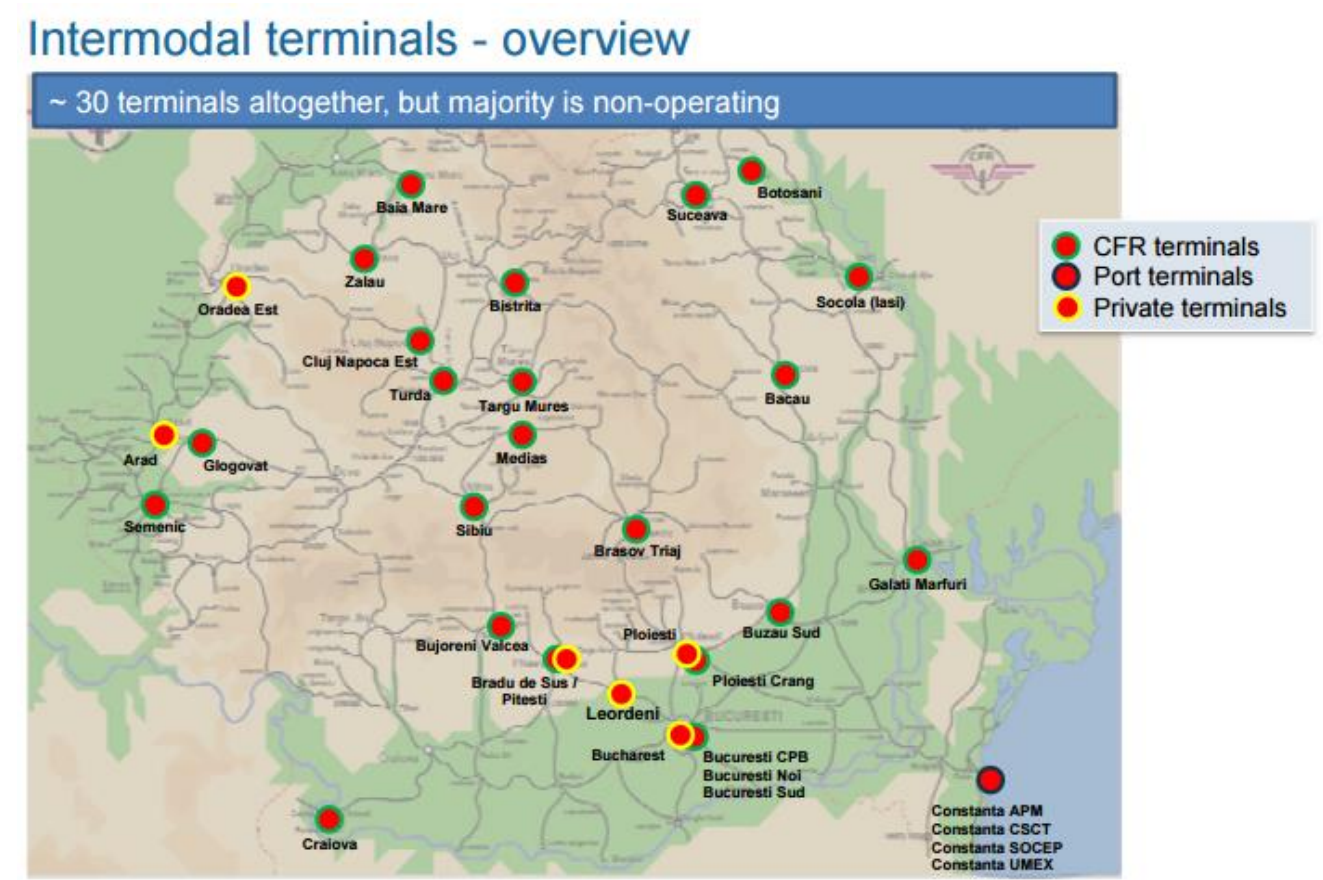

PICBE | 654

Figure 2. Intermodal Terminals in Romania

Source: COSMOS, 2013.

Intermodal terminals - Most active sites

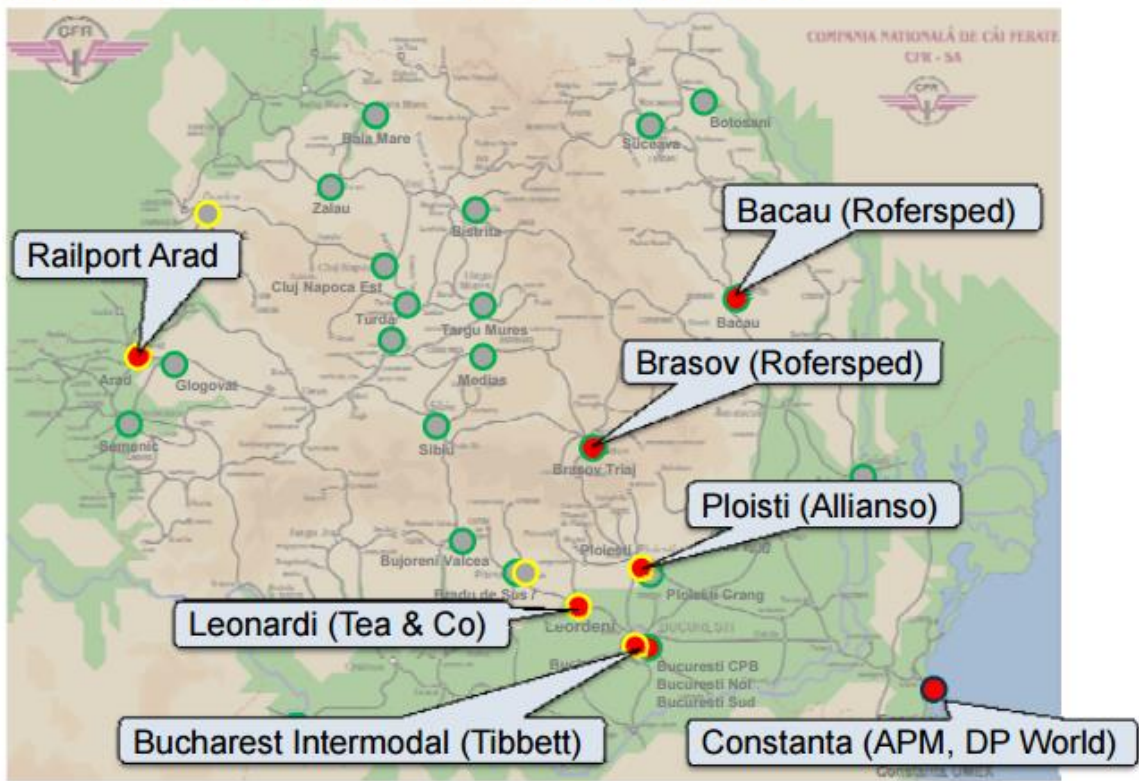

Figure 3. Intermodal Terminals -most active sites

Source: COSMOS, 2013.

As it can be understood, the intermodal transport system is in its early stages, disregarding the attention it had gained along the time. In his article, professor Dragu (2009) identified as the causes for the low progress the correlation knowledge about the intermodal transport -demand for intermodal transport services, as well as the lack of an adequate legal framework. 


\section{SWOT analysis}

In order to assess the potential of Romania to develop intermodal transport projects, a SWOT analysis was made. The starting point of this analysis was the one presented by Kombi Consult in the road map completed after the round table session and further developed according to the results of the desk research and the discussions with the professionals. The results are included in Table 1. SWOT analysis.

Table 1. SWOT analysis

\begin{tabular}{|c|c|}
\hline STRENGHTS & WEAKNESSES \\
\hline $\begin{array}{l}\text { Integration into the Rail Freight Corridor at EU } \\
\text { level }\end{array}$ & Abandoned/in poor state intermodal terminals \\
\hline $\begin{array}{l}\text { European funds for railway network } \\
\text { modernization and upgrading to EU standards }\end{array}$ & (PPP) legislation in Romania \\
\hline $\begin{array}{l}\text { Presence of Constanta Port on the Romanian } \\
\text { territory }\end{array}$ & $\begin{array}{l}\text { Lack of a management authority for coordinating } \\
\text { the development of intermodal transport and } \\
\text { gathering the available data }\end{array}$ \\
\hline $\begin{array}{l}\text { Presence of private terminals to be promoted as } \\
\text { successful stories (e.g. Rail Port Arad) }\end{array}$ & $\begin{array}{l}\text { Lack of incentives to stimulate the development of } \\
\text { intermodal transport }\end{array}$ \\
\hline $\begin{array}{l}\text { Presence of (even if non-functional) rail-road } \\
\text { terminals in Romania }\end{array}$ & $\begin{array}{l}\text { Lack of awareness of the benefits of intermodal } \\
\text { transport system }\end{array}$ \\
\hline $\begin{array}{l}\text { Availability of a strategy supporting the } \\
\text { intermodal transport }\end{array}$ & $\begin{array}{l}\text { Poor actual condition of the railway network } \\
\text { leading to poor railway services }\end{array}$ \\
\hline $\begin{array}{l}\text { Availability of lesson-learned from the previous } \\
\text { calls for proposals for the intermodal transport }\end{array}$ & $\begin{array}{l}\text { Outdated capacity and old infrastructure in the } \\
\text { Constanta Port }\end{array}$ \\
\hline $\begin{array}{l}\text { The modernization and upgrading of Bucuresti- } \\
\text { Constanta Railway line }\end{array}$ & $\begin{array}{l}\text { Clashing interests regarding the project promoters } \\
\text { and type of transport modes }\end{array}$ \\
\hline $\begin{array}{l}\text { Presence of industrial centers exporting goods } \\
\text { (e.g. automotive) }\end{array}$ & $\begin{array}{l}\text { Investment prioritization and alignment of } \\
\text { interests with the commercial stakeholders as } \\
\text { shortcomings }\end{array}$ \\
\hline Trade-oriented economy & $\begin{array}{l}\text { High investment costs for } \\
\text { modernization/upgrading/building of the } \\
\text { intermodal terminals }\end{array}$ \\
\hline \multicolumn{2}{|l|}{$\begin{array}{l}\text { Qualified companies acting in the rail and logistics } \\
\text { sectors }\end{array}$} \\
\hline OPPORTUNITIES & THREATS \\
\hline $\begin{array}{l}\text { Focus of EU policies on the development of } \\
\text { intermodal transport and modal shift }\end{array}$ & $\begin{array}{l}\text { Develop the railway network in due time to } \\
\text { benefit from the allocated EU funds }\end{array}$ \\
\hline $\begin{array}{l}\text { Availability of public and private } \\
\text { funding/financing schemes }\end{array}$ & $\begin{array}{l}\text { The liberalization of railway market - increased } \\
\text { cross-border competition }\end{array}$ \\
\hline $\begin{array}{l}\text { Best practices of implementing intermodal } \\
\text { projects in other countries }\end{array}$ & $\begin{array}{l}\text { The existing of missing links within the EU } \\
\text { transport network which will include additional } \\
\text { delay in the progress of intermodal transport }\end{array}$ \\
\hline Geographical position advantage & $\begin{array}{l}\text { The threat of developing parallel rail freight } \\
\text { networks overpassing/not including Romania }\end{array}$ \\
\hline The liberalization of railway market & $\begin{array}{l}\text { Fragile geopolitical context regarding Turkey and } \\
\text { Russia }\end{array}$ \\
\hline $\begin{array}{l}\text { Romania's membership in TRACECA international } \\
\text { program }\end{array}$ & \\
\hline
\end{tabular}

Source: Adapted by the author from COSMOS (2013). 


\section{Conclusions}

The article aims at assessing the potential of intermodal transport projects to be implemented in Romania. In this respect, a desk research and discussions with the professionals involved in the transport sector approaches were adopted. A SWOT analysis was elaborated as the next step. In this section the conclusions of the research are stated.

The potential of Romania to develop intermodal transport projects is very high, as it can be seen from the SWOT analysis and from the research conducted for this article, which clearly confirms the hypothesis mentioned earlier in this article. It is the high time for the intermodal transport to become a priority and make it happen as a functional network at national and international level. The liberalization, standardization of (railway) transport market (EU regulation no. 1315/2013) and the availability of policies favouring this mode of transport are crucial allies.

In line with the findings stated in COSMOS (2013), the intermodal transport system is not well developed in Romania. However, the fact that it has a dedicated strategy and it was the subject of funding axis (even if not successful) can be considered as an important starting point for future initiatives. The failures can be considered as lesson learned. As noted in the COSMOS (2013), there is a need for the revision of the strategy promoting the intermodal transport "taking into account the recent market development, terminals developed by the private sector in the meantime, shortcomings on the rail infrastructure and transparent rules for application by the market parties including realistic business plan" and "should investigate (re)-activating schemes in favour of intermodal transport". The strategy should align the political priorities and avoid the conflicting interests of public and private investment initiatives (for examples, the General Master Plan for Transport identified 11 multimodal centres to be developed, which can be understood as a way to prioritize and guide the development of such projects).

Moreover, the legal framework is still a burden for the development of the intermodal transport projects, a fact which reinforce the finding mentioned in the article of professor Dragu (2009) that the lack of an adequate legal framework hindered the rapid advancement of such projects. For a smooth implementation of intermodal transport project, the legislation should be revised, as for instance the PPP legislation in Romania which doesn't seem to work well, but which can support the development of intermodal transport projects in a PPP/the Juncker Plan framework (e.g. the terminal being owned by the state and the operations by a private company) or the Government Decision no. $581 / 1998$ which does not include the intermodal terminal among the network elements belonging to the National Railway Company "CFR" S.A..

In addition, there is a need for a coordinating body, fully dedicated towards the intermodal transport sector which will work on an integrated, country-level strategy for the development of intermodal terminals and intermodal transport network, as recommended in the COSMOS (2013), too. This coordinating body should involve professionals working in all transport modes to allow the integrated development of the modes into the new-born mode which is the intermodal transport.

As regards the entire transport sector, the identification of some sustainable funding and financing mechanisms for the intermodal transport projects is also a challenge required to be solved for the successful implementation of such projects.

Last, but not least, the fact that Romania is still at the initial stages of the development regarding the intermodal transport system is not necessarily a weakness, but 
it can be seen as an opportunity as well. Best practices and lesson learned from other countries regarding this mode of transport or the development of intermodal terminals can be disseminated via successful stories (such as Rail Port Arad).

To conclude, Romania needs the intermodal transport network to allow the modal shift required by Europe in the context of globalization and climate change and it has a good starting premises to support the development of intermodal transport projects.

PICBE | 657

\section{Acknowledgements}

We thank our colleagues from the Romanian Ministry of Transport and from The National Railway Company "CFR" S.A. (especially to Mr. Adrian Dragomirescu) for sharing their information and views with us to complete this article.

\section{References}

Adevarul, (2015, November, 26). Oradea, primul oraș din România cu terminal intermodal finanțat cu bani europeni. Retrieved from http://adevarul.ro/locale/oradea/oradeaoras-romania-terminal-intermodal-finantat-bani-europeni-1_5656396b7d919ed50 e96972a/index.html.

Caris, A., Macharis, C., and Janssens, G.K. (2013). Decision support in intermodal transport: A new research agenda. Computers in Industry, 64(2), 105-112.

Club Feroviar, (2013). Romania Railway business opportunities. Retrieved from http://catalog.clubferoviar.ro/wpcontent/uploads/2012/11/Brosura_infra.pdf.

Cosmos, (2013). Intermodal Round Table and Road Map for Romania, KombiConsult GmbH. Retrieved from http://www.intermodalcosmos.eu/content/e4/e291/e42/e337 /COSMOS_RoundTableRomania_final_2014-01-16_eng.pdf.

DIOMIS (2010). Developing Infrastructure \& Operating Models for Intermodal Shift (DIOMIS) - Evolution of Intermodal rail/road traffic in Central and Eastern European Countries by 2020, Romania. Retrieved from http://www.uic.org/diomis/IMG/pdf/ DIOMIS_Romania_info.pdf.

Dragu, V. (2009). Transporturile Intermodale - Soluţii Eficiente Pentru Economisirea Resurselor Şi Limitarea Efectelor Externe Negative, Buletin AGIR, 4, 168-171.

Donovan, A. (2000). Intermodal Transportation in Historical Perspective. Transportation law journal, 27(3), 317-362.

EU Regulation no. 1315/2013. Union guidelines for the development of the trans-European Network and repealing Decision no. 661/2010/EU. Retrieved from http://eurlex.europa.eu/legal-content/EN/TXT/PDF/?uri=CELEX:32013R1315\&from=EN.

EU Regulation no. 1316/2013. Connecting Europe Facility, amending Regulation (EU) No 913/2010 and repealing Regulations (EC) No 680/2007 and (EC) No 67/2010. Retrieved from http://eur-lex.europa.eu/LexUriServ/LexUriServ.do?uri=0J:L:2013: 348:0129:0171:EN:PDF.

European Parliament (2015). How the EU budget in spent. Retrieved from http://www.europarl.europa.eu/RegData/etudes/BRIE/2015/565903/EPRS_BRI(201 5)565903_EN.pdf.

Eurostat (2016). Greenhouse gas emissions, analysis by source sector, EU-28, 1990 and 2014 (percentage of total), Retrieved from http://ec.europa.eu/eurostat/statistics- 
explained/index.php/File:Greenhouse_gas_emissions,_analysis_by_source_sector,_E U-28,_1990_and_2014_(percentage_of_total)_new.png

Fourth Railway Package (2016). The 4th railway package: Improving Europe's railways. Retrieved from http://www.consilium.europa.eu/en/policies/4th-railwaypackage/.

General Master Plan for Transport (2016). Sinteza Strategiei Master Planului General de Transport. http://mt.gov.ro/web14/strategia-in-transporturi/master-plan-generaltransport/documente-master-plan1/613-documente-master-plan-general-detransport.

Government Decision no. 581/1998 - Hotararea de Guvern nr. 581/1998 privind infiintarea Companiei Nationale de Cai Ferate "CFR"-S.A. prin reorganizarea Societatii Nationale a Cailor Ferate Romane. Retrieved from http://www.legex.ro/Hotararea-581-199816262.aspx.

Law no. 203/2003 -Legea 203/2003 (r1) privind realizarea, dezvoltarea si modernizarea retelei de transport de interes national si european, vol. Partea I nr. 89, 2005. Retrieved from http://www.mt.ro/web14/documente/strategie/strategii_sectoriale /legea_203_din_2003.pdf.

Macharis, C., \& Bontekoning, Y. M. (2004). Opportunities for OR in intermodal freight transport research: A review. European Journal of Operational Research, 153(2), 400416.

Macharis, C., Caris, A., and Jourquin, B. (2011). A decision support framework for intermodal transport policy. European Transport Research Review, 3(4), 167-178.

Mathisen, T. A., and Hanssen, T.-E. S. (2014). The academic literature on intermodal freight transport. Transportation Research Procedia, 611-620.

Ministry of Transport (2011). Strategia de Transport Intermodal în România 2020. Retrieved from http://mt.gov.ro/web14/documente/strategie/strategii_ sectoriale/ strategie_de_transport_intermodal_text.pdf.

Nistor, Flip (2013). Lantul logistic in transportul intermodal. http://www.uuooi.org/english/files/13th_lecture_logistics_chain_for_intermodal_tr ansport.pdf.

Pedersen, M. B., Madsen, O. B., and Nielsen, O. A. (2005). Optimization models and solution methods for intermodal transportation. Doctoral dissertation, Technical University of DenmarkDanmarks Tekniske Universitet. Department of TransportInstitut for Transport, Traffic ModellingTrafikmodeller.

SOP-T Guide for Applicants (2011). Sectoral Operational Program - Transport - Priority axis -3. Modernization of the transport sector aiming at higher degree of environmental protection, human health and passenger safety- Major Domain of intervention 3.1. The promotion of intermodal transport. http://old.fonduriue.ro/res/filepicker_users/cd25a597fd-62/Finantari/POS_Transport/DMI-1/Ghidul .solicitantului-DMI-3.1-2011.pdf.

SOP-T Guide for Applicants (2014). Sectoral Operational Program - Transport - Priority axis -3. Modernization of the transport sector aiming at higher degree of environmental protection, human health and passenger safety- Major Domain of intervention 3.1. The promotion of intermodal transport. Retrieved from http://www.ampost.ro/fisiere/pagini_fisiere/Ghidul_solicitantului_intermodal_final _26nov2014.pdf. 
The Investment Plan for Europe (2014). Retrieved from https://ec.europa.eu/priorities/jobs-growth-and-investment/investment-plan_en.

White Paper (2011). Roadmap to a Single European Transport Area - Towards a competitive and resource efficient transport system.

PICBE | 659 